\title{
Serum Leptin and Nitric Oxide in Chronic Obstructive Pulmonary Disease
}

\author{
Mohamed Ahmed Abd-elmoety* and Ismail S Mohamed** \\ Departments of Biochemistry* and Chest Diseases** \\ Sohag Faculty of Medicine, Sohag University
}

\begin{abstract}
Objective: Unexplained weight loss is common in patients with chronic obstructive pulmonary disease (COPD). Leptin not only is a critical regulator of body weightand appetite, but also serves as an immune-modulator. Nitric oxide (NO) is a potent relaxant of bronchial and pulmonary artery and leptin has a regulatory role in its synthesis. In the present study, the association of serum leptin levels with nitric oxide metabolites (NO) in COPD was investigated. Methods: Serum leptin and NO levels were measured in COPD patients [males $(n=18)$ and females $(n=15)]$ above forty years old compared with control group $(n=30)$ in the same age matched group. Serum leptin levels were measured by enzyme linked immune sorbant assay (ELISA) technique. NO level was measured by spectrophotometric method. Results: Serum mean leptin level was significantly lower in COPD male group $(9.7 \pm 4.1 \mathrm{pg} / \mathrm{ml})$ and female group $(11.1 \pm 3.7 \mathrm{pg} / \mathrm{ml}$ ) than corresponding control group (male: $12.7 \pm 1.4$ $\mathrm{pg} / \mathrm{ml}$ and female: $15.1 \pm 1.5 \mathrm{pg} / \mathrm{ml})$ ( $p<0.01$ in both). Also, serum nitric oxide (nitrite and nitrate) in COPD male $(18.4 \pm 3.7 \mu \mathrm{mol} / L)$ and female group $(15.9 \pm 5.6$ $\mu \mathrm{mol} / \mathrm{L}$ ) which was lower than corresponding control group (male: $21.2 \pm 1.9 \mu \mathrm{mol} / \mathrm{L}$ and female: $24.2 \pm 2.5 \mu \mathrm{mol} / \mathrm{L})$ ( $p<0.01$ in both). Conclusions: low serum leptin associated with COPD is related with low BMI. Associated low nitric oxide serum level may be related to the pathogenesis of COPD.
\end{abstract}

\section{Abbreviations:}

BMI Body mass index

COPD Chronic obstructive pulmonary disease

ELISA Enzyme linked immune sorbant assay

NO Nitric oxide

\section{INTRODUCTION}

Chronic obstructive pulmonary disease (COPD) is a progressive disease characterized by a decrease in the airways diameter that increases their resistance to airflow ${ }^{(\mathbf{1})}$. Unexplained weight loss, commonly observed in patients with COPD, is clinically important because it is an independent risk factor of mortality in these patients ${ }^{(2)}$. Cachectic patients with COPD show abnormalities of the autonomic nervous system, neuroendocrine function, and energy expenditure $^{(3)}$. However, its pathophysiologic mechanisms are poorly understood ${ }^{(4)}$.

Leptin is a peptide hormone secreted mainly by white adipose 
tissue. Its level is regulated by several factors as starvation and hormones such as insulin ${ }^{(5)}$ and ovarian sex steroids $^{(\mathbf{6})}$ stimulate leptin secretion. Also, Glucocorticoids ${ }^{(7)}$ and testosterone $^{(6)}$ have an inverse relationship with leptin. It acts on hypothalamic centers to regulate food intake and energy expenditure. Leptin is, also, involved in the regulation of various other physiological processes including carbohydrate and lipid metabolism, gastrointestinal and cardiovascular function, inflammation, immune response and reproduction $^{(\mathbf{8})}$. Serum leptin concentration is proportionated to the amount of white adipose tissue and is markedly increased in obese individuals ${ }^{(\mathbf{9})}$.

The reported rise of blood leptin concentrations following acute infection and in chronic inflammation suggests that leptin may actively participate in the immune network and host defense ${ }^{(9)}$. Indeed, leptin levels are rapidly increased by many acute phase cytokines, such as tumor necrosis factor alpha (TNF- $\alpha$ ), interleukin-1 (IL-1), and interleukin-6 $(\mathrm{IL}-6)^{(\mathbf{1 0 )}}$.

Nitric oxide (NO) is produced by endothelial cells and the terminal guanidine nitrogen atom(s) of Larginine are the physiological precursors of endothelium-derived $\mathrm{NO}^{(11)}$. Masaki et al. (1989) showed that endogenous NO was a potent relaxant of isolated canine tracheal and bronchial smooth muscle and pulmonary artery ${ }^{\mathbf{( 1 2})}$. NO is thought to relax smooth muscle by increasing cGMP ${ }^{(13)}$ or by opening $\mathrm{Ca}^{2+}$ activated $\mathrm{K}^{+}$channels which promotes a relaxation response ${ }^{(\mathbf{1 4})}$. Endogenous
NO may attenuate mast cell mediator release, resulting in reduced leukocyte adhesion and vascular leakage in inflammatory airways disease $\mathrm{e}^{(\mathbf{1 5})}$.

Although leptin receptors are expressed in endothelial cells ${ }^{(\mathbf{1 6})}$ but its effect on NO generation is controversial. In vitro, leptin stimulates endothelial NO production $^{(\mathbf{1 7}, 18)}$ and induces NOmediated smooth muscle relaxation ${ }^{(19,20)}$. The results of in vivo studies are less clear. Some authors have observed the involvement of $\mathrm{NO}$ in leptin-induced vasodilatation ${ }^{(21)}$, whereas others have not ${ }^{(22,23)}$. In addition, leptin may induce NOindependent smooth muscle relaxation $^{(21)}$. Frühbeck and GomezAmbrosi (2001) observed increased plasma concentration of nitric oxide metabolites (nitrites and nitrates) following leptin administration ${ }^{(24)}$. Apart from endothelial cells, leptin may stimulate NO synthesis in other tissues such as adipocytes ${ }^{(25)}$, macrophages ${ }^{(26)}$ and the central nervous system ${ }^{(27)}$. In addition, plasma NO level is affected by factors other than NO production such as dietary nitrates and renal excretory function.

The present study was undertaken to investigate the association of plasma leptin levels and NO metabolites (nitrites plus nitrates) levels in COPD.

\section{PATIENTS \& METHODS}

The study population included 33 patients with COPD (18 males and 15 females) and 30 healthy persons as a control group, of average age ( $>40$ years). The patients are with clinically stable mild to severe COPD $\left(\mathrm{FEV}_{1}\right.$ 
30-80\% predicted) (GOLD I-III) ${ }^{(\mathbf{2 8})}$. Forced expiratory volume in $1 \mathrm{~s}$ (FEV1) was calculated from the flow volume curve using a spirometer (Jaeger SN.:-692669 German) applied before and $15 \mathrm{~min}$ after inhalation of a $\beta_{2}$-agonist via a metered-dose inhaler. $\mathrm{FEV}_{1}$ was expressed as a percentage of reference values ${ }^{(29)}$. Exclusion criteria included cardiovascular diseases, renal, metabolic, hormonal diseases, smoking, alcohol or receiving any drug therapy such as lipid lowering drugs, vitamins, antioxidants, or antihypertensive drugs. Past history of respiratory disease other than COPD was excluded. The studied population was taken from outpatient clinic of the respiratory diseases, Sohag University Hospital, Sohag Faculty of Medicine, Sohag University, in the period from March 2006 to January 2007.

Sample Collection and isolation of plasma

Blood was obtained from all subjects in the overnight fasting state (from 9:00 PM on the previous night) by venipuncture at 9.00 AM. Blood was collected in glass tubes containing ethylenediaminetetra acetic acid. Blood was centrifuged at $1600 \mathrm{~g}$ for $15 \mathrm{~min}$ at $4^{\circ} \mathrm{C}$, and plasma was collected and stored at $-70^{\circ} \mathrm{C}$ until analysis.

Leptin Assay

The DSL-10-23100 ACTIVE®

Human Leptin ELISA is an enzymatically amplified "two-step" sandwich-type immunoassay (30).

\section{Nitric oxide metabolites Assay}

NO levels were measured as the concentration of nitrate plus nitrite in the plasma in two step process. The first step is the reduction of nitrate $\left(\mathrm{NO}_{3}\right)$ to nitrite $\left(\mathrm{NO}_{2}\right)$ by nitrate reductase. The second step is the addition of the Griess Reagent which converts nitrite into deep purple azo compound. The sample was deproteinized with $\mathrm{ZnSO}$, and the concentration of nitrite was measured spectrophotometrically at $540 \mathrm{~nm}$ using the Griess reaction with commercial kit (Cayman chemical, catalog No 780001, Germany).

\section{Statistical Analysis:}

Values were expressed as mean, medians (range) and \pm standard deviation (SD). For both serum leptin and NO in comparisons of controls and COPD patients, unpaired Student's $t$-test was used. Differences with $\mathrm{p}$ values $\leq 0.05$ were considered significant by using SPSS software (release 10.0).

\section{RESULTS}

Thirty three patients (male $\mathrm{n}=18$ and female $\mathrm{n}=15$ ) above forty with mild to severe COPD $\left(\mathrm{FEV}_{1}\right.$ range 30 $80 \%$ predicted) were included in the present study. The average age in years in COPD was 40.1 - 48 in male and $40-49$ in female and in control group was in male 40.1 - 48 and in female 40.2-55.1. Baseline characteristics are shown in table 1 
Table (1): Demographic and clinical data of the COPD patients and control group

\begin{tabular}{|l|c|c|c|c|}
\hline \multirow{2}{*}{ Age } & \multicolumn{2}{|c|}{ Control (n= 30) } & \multicolumn{2}{c|}{ COPD (n= 33) } \\
\cline { 2 - 5 } & Male & Female & Male & Female \\
\hline Weight & $43.3 \pm 2.6$ & $44.5 \pm 4.2$ & $43.3 \pm 3.7$ & $42.2 \pm 2.2$ \\
\hline Height & $67.4 \pm 5.9$ & $97.1 \pm 7$ & $60.2 \pm 10.6^{*}$ & $70.1 \pm 10^{*}$ \\
\hline BMI (Kg/M $\mathbf{M}^{\mathbf{2})}$ & $1.8 \pm 0.1$ & $1.7 \pm 0.1$ & $1.8 \pm 0.03$ & $1.7 \pm 0.1$ \\
\hline Ex-smoker & $25.1 \pm 2.1$ & $28.1 \pm 3.6$ & $19.2 \pm 3.5^{*}$ & $21.4 \pm 3.2^{*}$ \\
\hline $\mathbf{( \% ) F E V}$ & - & - & 14 & - \\
\hline $\mathbf{( \% ) F V C}$ & $83.8 \pm 2.8$ & $82.4 \pm 1.9$ & $42.1 \pm 5.3^{*}$ & $41.7 \pm 4.3^{*}$ \\
\hline FEV1/FVC & $99.1 \pm 4.6$ & $96.3 \pm 3.7$ & $67.5 \pm 2.4^{*}$ & $67.5 \pm 2.3^{*}$ \\
\hline
\end{tabular}

Age in years, weight in $\mathrm{Kg}$, height in meter

* means that $P<0.05$ between these value and corresponding same sex in control group).

Leptin was detected in serum samples of control group and COPD patients (fig.1A). The mean value of serum leptin was significantly lower in COPD patients $(10.3 \pm 3.9 \mathrm{ng} / \mathrm{ml})$ than that in control group $(13.9 \pm 1.9$

Serum Leptin in Control and COPD

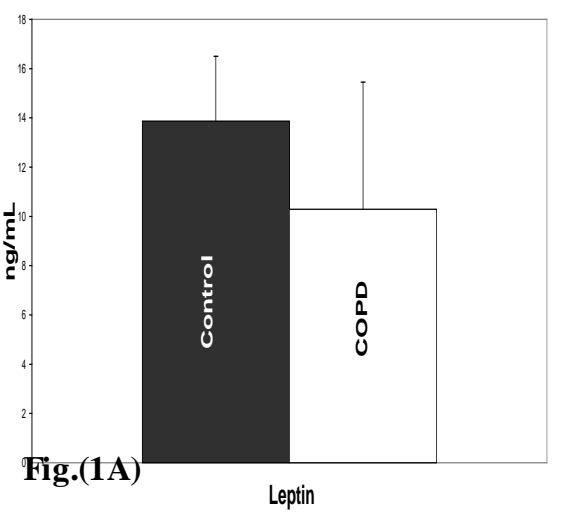

$\mathrm{ng} / \mathrm{ml}$ ). Also, the mean of serum NO was significantly lower in COPD patients $(16.9 \pm 5.2 \mu \mathrm{mol} / \mathrm{L})$ than that in control group $(22.7 \pm 2.6 \mu \mathrm{mol} / \mathrm{L})$ (figure 1B).

Figure (1): Serum leptin (1A) and NO (1B) in control (Black columns) and COPD (white columns) groups.

In COPD patients, serum leptin and NO levels were significantly lower in both male and female groups compared to the mean of both male and female control group (Table 2). To compare the serum leptin level to the change in the BMI, levels of serum leptin was divided on BMI. 
Leptin / BMI of each case and that value had no significant change in male and female control group compared to the corresponding sex of COPD group (Table 2)

Table (2): Biochemical characters of Control and COPD groups.

\begin{tabular}{l|lcll}
\hline & Control & \multicolumn{3}{c}{ COPD } \\
\cline { 2 - 5 } & Male & Female & Male & Female \\
\hline Leptin & $12.7 \pm 1.4$ & $15.1 \pm 1.5$ & $9.7 \pm 4.1^{*}$ & $11.1 \pm 3.7^{*}$ \\
Leptin/BMI & $0.4 \pm 0.2$ & $0.4 \pm 0.1$ & $0.5 \pm 0.2$ & $0.5 \pm 0.2$ \\
No & $21.2 \pm 1.9$ & $24.2 \pm 2.5$ & $18.4 \pm 3.7^{*}$ & $15.9 \pm 5.6^{*}$ \\
\hline
\end{tabular}

Serum leptin in $\mathrm{ng} / \mathrm{ml}, \mathrm{NO}$ in $\mu \mathrm{mol} / \mathrm{L}$.

* means that $P<0.05$ between these value and corresponding same sex in control group.

\section{DISCUSSION}

Recent studies point to the role of bioactive mediator secreted by white adipose tissue such as leptin. The short forms of leptin receptor are expressed in choroid plexus, kidney, gonads, liver, lung and vascular endothelium, where they mediate leptin transport into the brain ${ }^{(\mathbf{8})}$. The role of leptin on the lung was demonstrated to have a proinflammatory effect in the lung, although such effects have been reported in other systems (31 and 32), and also promotes lung growth ${ }^{(33)}$.

Level of serum leptin was for a long time controversially associated with COPD patients. Noriaki et al. (1999) and Takabatake et al. (1999) found that serum leptin values were significantly lower in patients who had COPD than in control subjects $^{(34 \& 35)}$. But, Creutzberg, et al. (2000) found that plasma leptin was elevated in exacerbating COPD patients $^{(\mathbf{3 6})}$. Leptin regulates appetite and increased circulating leptin may contribute to the anorexia observed in these patients. Leptin is, also, directly up-regulated in inflamed COPD lung ${ }^{(16)}$.

High serum leptin levels and obesity (high body weight) are associated with female than in male in both control and COPD. Serum leptin is produced by adipose tissue leptin, so its level is higher in women than in men ${ }^{(37)}$. Also, the expression of serum leptin is higher in female than male and this may be due to the effect of sex hormones where it can be inhibited by testosterone and increased by ovarian sexhormones ${ }^{(\mathbf{6})}$.

Circulating leptin levels are lower in COPD patients compared with healthy controls but that level was associated with low body weight probably due to reduced white adipose tissue. Apart from its satiety effect, leptin is, also, recognized to induce an inflammatory response ${ }^{(38)}$. Elevated serum leptin in COPD patients was partially explained by acute exacerbation of $\mathrm{COPD}^{(36)}$ or systemic glucocorticosteroid administration ${ }^{(39)}$. The low serum leptin in COPD may be related to have one of the following reasons. First, hypoxic COPD patients were found to have impaired glucose 
tolerance and hyperinsulinemia ${ }^{(5)}$. Second hypoxic gonads and low female sex hormone ${ }^{(6)}$ but it is most probably related to low body weight. In addition, leptin potentates expression of nitric oxide synthase in murine macrophage ${ }^{(40)}$.

The significant association between low total NO and COPD may be related to the pathogenesis of COPD. Bronchial constriction ${ }^{(41)}$, increasing of pulmonary vascular resistance with pulmonary hypertension $^{(\mathbf{4 2})}$ and decreasing in ciliary beat frequency ${ }^{(43)}$ with accumulation of intra-bronchiolar stick secretion are the pathology with COPD. NO had many pharmacological effects on the airways, first, it relaxed the pulmonary artery which preconstricted with hypoxia ${ }^{(\mathbf{1 2})}$. NO was shown to induce pulmonary vasodilatation $^{\left({ }^{(4)}\right)}$.

Endogenous NO modulates cholinergic neurotransmission by inhibiting acetylcholine release ${ }^{(41)}$ or reducing the release of cyclooxygenase products ${ }^{(\mathbf{4 0})}$ to perform its bronchodilator action on airway smooth muscle. Nonselective $\beta_{2^{-}}$ adrenoceptor agonist isoprenaline was shown to up-regulate the ciliary beat frequency by a NO-dependent mechanism ${ }^{(\mathbf{4 3})}$. An increase in ciliary beat frequency would aid in the clearance of harmful substances contained within the mucus mesh.

In conclusion, in spite of low circulating leptin in COPD, that change is related to low BMI. Low serum leptin is associated with low concentrations of serum NO in these patients. Low level of serum NO (not leptin) has a role in the pathogenesis of COPD. Role of serum NO in the prognosis and progression of COPD needs further study.

\section{REFERENCES}

1. Siafakas $N$, Vermeire $P$, Pride N, Paoletti P, Gibs on J, and Howard P. (1995): Optimal assessment and management of chronic obstructive pulmonary disease (COPD): a consensus statement of the European Respiratory Society (ERS). Eur. Respir. J., 8: 1398-1420.

2. Schols A, Soeters $\mathbf{P}$, Dingemans $A$, Moster R, Frantzen $P$, and Wounders E. (1993): Prevalence and characteristic nutritional depletion in patients with stable COPD eligible for pulmonary rehabilitation. Am. Rev. Respir. Dis., 147: 1151-1156.

3. Koehler F, Doehner W, Hoernig S, Witt C, Anker S, and John M. (2006): Anorexia in chronic obstructive pulmonary disease - Association to cachexia and hormonal derangement Int. $J$. Cardiol.,119(1) 83-89.

4. Schols A, Buurman W, Brekel $A$, Dentener $M$, and Wounders E. (1996): Evidence for a relation between metabolic derangement and increased levels of inflammatory mediators in a subgroup of patients with chronic obstructive pulmonary disease. Thorax, 51: 819-824.

5. Boden G, Chen X, Kolaczynski $J$ and Polansky M. (1997): Effects of prolonged hyperinsulinemia on serum leptin in normal human subjects. $J$. Clin. Invest., 100: 1107-1113. 
6. Castracane V, Kraemer R, Franken M, Kraemer $G$ and Gimpel T. (1998): Serum leptin concentration in women: effect of age, obesity, and estrogen administration. Fertil. Steril., 70: 472-477.

7. Elimam A, Knutsson U, Bronnegard M, Stierna P, Albertss on W, Marcus C. (1998): Variations in glucocorticoid levels within the physiological range affect plasma leptin levels. Eur. J. Endocrinol., 139(6): 61520.

8. Margetic S, Gazzola C, Pegg G, and Hill R. (2002): Leptin: a review of its peripheral actions and interactions. Int. J. Obes. Relat. Metab. Disord., 26: 14071433.

9. Considine R, Sinha M, Heiman M, Kriauciunas A, Stephens T, and Nyce $M$. (1996): Serum immunoreactive-leptin

concentrations in normal-weight and obese humans. N. Engl. J. Med., 334: 292-295.

10. Sarraf $P$, Frederich $R$, Turner E, Ma G, Jaskowiak N, Rivet D 3rd, Flier J, Lowell B, Fraker $D$, and Alexander H. (1997): Multiple cytokines and acute inflammation raise mouse leptin levels: potential role in inflammatory anorexia. J. Exp. Med., 185: 171-175.

11. Mayer B, Schmidt, K, Hubert $P$, and Bohme E. (1989): Biosynthesis of endotheliumderived relaxing factor: a cytosolic enzyme in porcine aortic endothelial cells Ca2+dependently converts L-arginine into an activator of soluble guanylyl cyclase. Biochem Biophys. Res. Commun., 164: 678- 685.

12. Masaki $Y$, Munakata $M$, Ukita H, Homma Y, and Kawak ami Y. (1989): Nitric oxide (NO) can relax canine airway smooth muscle. Am. Rev. Respir. Dis., 139: A350.

13. Heaslip R, Giesa F, Rimele $T$, and Grimes D. (1987): Coregulation of tracheal tone by cyclic AMP and cyclic GMP dependent mechanisms. $J$. Pharmacol. Exp. Ther., 243: 1018- 1026.

14. Carvajal J, Germain A, Huidobro-Toro $J$, and Weiner C. (2000): Molecular mechanism of cGMP-mediated smooth muscle relaxation. J. Cell Physiol., 184: 409- 420.

15. Holgate S. (1997): The cellular and mediator basis of asthma in relation to natural history. Lancet, 350: 5-9.

16. Broekhuizen $R$, Vernooy $J$, Schols A, Dentener $M$, and Wouters E (2005): Leptin as local inflammatory marker in COPD. Respiratory Medicine, 99: 70-74.

17. Betowski J, Wójcicka $G$ and Borkowska E. (2002): Human leptin stimulates systemic nitric oxide production in the rat. Obes. Res., 10: 939-946.

18. Vecchione C, Maffei A, Colella $S$, Aretini A, Poulet $R$, and Frati G. (2002): Leptin effect on endothelial nitric oxide is mediated through Akt endothelial nitric oxide synthase phosphorylation pathway. Diabetes, 51: 168-173. 
19. Kimura $K$, Tsuda $K$, Baba $A$, Kawabe $T$, Boh-oka $S$, and Ibata M. (2000): Involvement of nitric oxide in endotheliumdependent arterial relaxation by leptin. Biochem. Biophys. Res. Commun., 273: 745-749.

20. Lembo G, Vecchione $C$, Fratta L, Marino G, Trimarco V, and d'Amati G. (2000): Leptin induces direct vasodilation through distinct endothelial mechanis ms. Diabetes, 49: 293297.

21. Frühbeck G. (1999): Pivotal role of nitric oxide in the control of blood pressure after leptin administration. Diabetes, 48: 903-908.

22. Jalali A, Morgan D, Sivitz W, Correia M, Mark A and Haynes W. (2001): Does leptin cause functional peripheral sympatholysis?. Am. J. Hyperten., 14: 615-618.

23. Mitchell J, Morgan D, Correia M, Mark A, Sivitz W and Haynes W. (2001): Does leptin stimulate nitric oxide to oppose the effects of sympathetic activation?. Hypertension, 38: 1081-1086.

24. Frühbeck G, and GomezAmbrosi J. (2001): Modulation of the leptin-induced white adipose tissue lipolysis by nitric oxide. Cell Signal, 13: 827-833.

25. Mastronardi $C, Y u ~ W$ and McCann S. (2002): Resting and circadian release of nitric oxide is controlled by leptin in male rats. Proc. Natl. Acad. Sci. (U. S. A.), 99: 5721-5726.

26. Fortuno A, Rodriguez A, Gomez-Ambrosi J, Muniz P, Salvador J, and Diez J. (2002):
Leptin inhibits angiotensin IIinduced intracellular calcium increase and vasoconstriction in the rat aorta. Endocrinology, 143: 3555-3560.

27. Yu W, Walczewska A, Karanth $S$ and McCann S. (1997): Nitric oxide mediates leptin-induced luteinizing hormone-releasing hormone (LHRH) and leptininduced LH release from the pituitary gland. Endocrinology, 138: 5055-5058.

28. Michelle J, Rosa $C$, Steve $B$, Ross V, and Gary P. (2006): Therapeutic prospects to treat skeletal muscle wasting in COPD (chronic obstructive lung disease). Pharmacology and Therapeutics, 109: 162 - 172.

29. Quanjer P. (1993): Standardized lung function testing Official statement of the European Respiratory Society. Eur. Respir. J., 6 (suppl.16): 1-100.

30. Batler M, Moore J, Marawiecki $A$ and Nicolson: Comparsion of leptin levels in prader-willi syndrome and control individwals. Am. J. Med. Genet., 75: 7-12.

31. Ikejima $\mathbf{K}$, Honda $H$, Yoshikawa M, Hirose $M$, Kitamura T, and Takei $Y$. (2001): Leptin augments inflammatory and profibrogenic responses in the murine liver induced by hepatotoxic chemicals. Hepatology, 34(2): 288-297.

32. Matarese G, Sanna V, Di Gi acomo A, Lord G, Howard J and Bloom S. (2001): Leptin potentiates experimental autoimmune encephalomyelit is in 
SJL female mice and confers susceptibility to males. Eur. J. Immunol., 31, 324- 1332.

33. Tsuchiya $T$, Shimizu H, Horie $T$ and Mori M. (1999): Expression of leptin receptor in lung: leptin as a growth factor. Eur. J. Pharmacol., 365: 273279.

34. Noriaki T, Hidenori $N$, Shuichi A, Toshihiko H, Hiroshi S, Hideki Y, Shuichi $K$, and Hi tonobu T. (1999): Circulating leptin in patients with chronic obstructive pulmonary disease. Am. J. Respir. Crit. Care Med., 159: 1215-1219.

35. Takabatake N, Nakamura $H$, Abe $\mathrm{S}$, Hino T, Saito H, and Yuki $\mathrm{H}$. (1999): Circulating leptin in patients with chronic obstructive pulmonary disease. Am. J. Respir. Crit. Care Med., 159:1215-9.

36. Creutzberg E, Wouters E, Vanderhoven-Augustin I, Dentener $\mathrm{M}$, and Schols A. (2000): Disturbances in leptin metabolism are related to energy imbalance during acute exacerbations of chronic obstructive pulmonary disease. Am. J. Respir. Crit. Care Med., 162: 1239-1245.

37. Rosenbaum $M$, Nicolson $M$, Hirsch J, Heymsfield S, Gallagher D, and Chu F. (1996): Effects of gender, body composition, and menopause on plasma concentrations of leptin. J. Clin. Endocrinol. Metab., 38: 266-274.

38. Dixit V, Schaffer $E$, Pyle $R$, Collins G, Sakthivel S, Palaniappan R. (2004): Ghrelin inhibits leptin- and activation induced proinflammatory

cytokine expression by human monocytes and $\mathrm{T}$ cells. J. Clin. Invest., 114: 57- 66.

39. Jie L, Fanghong $L$ and Allan Z. (2006): Inflammation and leptin Drug Discovery Today: Disease mechanisms, 3: 387-393.

40. Raso G, Pacilio M, Es posito E, Coppola A, Di Carlo R, and Meli R. (2002): Leptin potentiates IFN-gamma-induced expression of nitric oxide synthase and cyclo-oxygenase-2 in murine macrophage J774A.1. Br. J. Pharmacol., 137: 799-804.

41. Kakuyama M, Ahluwalia A, Rodrigo $J$, and Vallance $P$. (1999): Cholinergic contraction is altered in nNOS knockouts. Cooperative modulation of neural broncho-constriction by nNOS and COX. Am. J. Respir. Crit. Care Med., 160(6): 2072-8.

42. Dinh-Xuan A, Higenbottam T, Clelland C, Pepke-Zaba J, Cremona G, Butt A, Large S, Wells $F$, and Wallwork $J$. (1991): Impairment of endothelium-dependent pulmonary-artery relaxation in chronic obstructive lung disease. N. Engl. J. Med., 324(22): 153947.

43. Jain B, Rubinstein I, Robbins $R$, Leise $K$, and Sisson $J$. (1993): Modulation of airway epithelial cell ciliary beat frequency by nitric oxide. Biochem. Biophys. Res. Commun., 191(1): 83-8.

44. Archer S, Rist $K$, Nelson D, DeMaster E, Cowan $N$, and Weir E (1990): Comparison of the hemodynamic effects of nitric 


\section{دور هرمون اللبتن وأوكسيد النيتريك فى حالات ضيق الشعب الهوائية المزمن}

$$
\text { محمد أحمد عبد المعطى" ، د.إسماعبل سبي محمد"* }
$$

قسمي الكيمياء الحيوية الطبيةُق الأمر اض الصدرية**بكلية الطب البشرى-جامعة سوهاج

إن من أهم مظاهر ضيق الشعب الهوائية المزمن الدال على تطور هذا المرض هو نقصان الوزن المستمروحيث أن هرمون اللبتن من أهم الهرمونات التى لها دور لبس فقط فى التحكم بالوزن هين

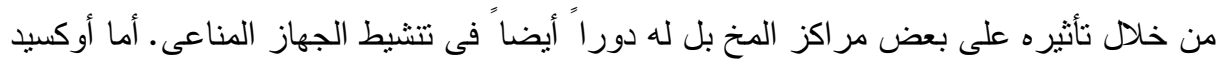
النيتريك فله دور في ارتخاء الثعب الهو ائية والثريان الرئوى والذى يعتمد فى تخليقه على هرمون اللبتقد اجريت هذه الدراسة لمعرفة تأثثر ضيق الثعب الهوائية المزمن على هرمون اللبتن وأوكسيد

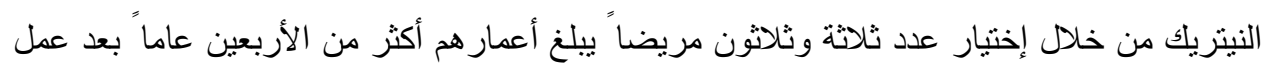
كافة الفحوصات و التحاليل للتأكد من وجود ضيق بالثعب الهو ائية المزمن لديهم ومقارنتهم بعدد ثثلاثون

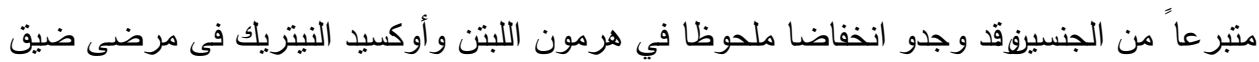
الشعب الهو ائية المزمن عن غير المصابينفقد تم مقارنة هرمون اللبنن بوزن كل مريض على حدة ونى

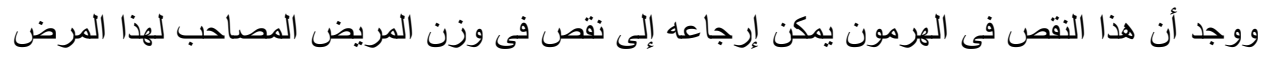

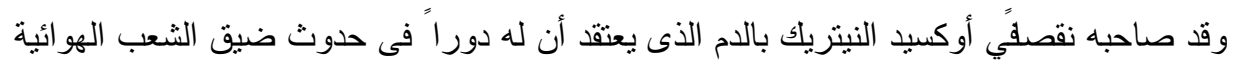
المزمن. 